ESPAÇO TEMÁTICO: TERRA, TERRITÓRIO E AMÉRICA LATINA

\title{
Concentração fundiária, quilombos e quilombolas: faces de uma abolição inacabada
}

\author{
Alcione Ferreira Silva ${ }^{1}$ \\ https://orcid.org/0000-0001-7178-8067 \\ ${ }^{1}$ Universidade Estadual da Paraíba, Departamento de Serviço Social, Campina Grande-PB, Brasil
}

\section{Concentração fundiária, quilombos e quilombolas: faces de uma abolição inacabada}

Resumo: Neste artigo, examinamos a interconexão entre a colonização na América Portuguesa, a concentração fundiária e o processo de escravização e libertação da população negra no Brasil, evidenciando o impacto dessa interconexão sobre o acesso à terra para quilombos e quilombolas. Por objetivo, buscamos compreender a importância dos territórios tradicionalmente ocupados, como meio de fortalecimento da experiência de liberdade nas comunidades quilombolas. Para tanto, recorremos à pesquisa bibliográfica e documental a partir de documentos orais, com abordagem qualitativa e uso da metodologia da história oral, sob a perspectiva de análise materialista, histórica e dialética. Concluímos que, em face do processo socio-histórico de base colonial-escravocrata, as dificuldades estruturais de acesso à titulação dos territórios quilombolas atuam como mecanismos que perpetuam sequelas advindas do período da escravidão, nas relações de trabalho e vida dos(as) quilombolas brasileiros, impondo restrições à experiência de liberdade, mesmo após a Abolição.

Palavras-chave: Concentração fundiária. Liberdade. Comunidades quilombolas.

\section{Land concentration, quilombos and quilombolas: faces of an unfinished abolition}

Abstract: In this article, we examine the interconnection between colonization in Portuguese America, land concentration and the process of enslavement and liberation of the black population in Brazil, evidencing the impact of this interconnection on access to land for quilombos and quilombolas. For this, we resort to bibliographic and documentary research based on oral documents, with a qualitative approach and the use of oral history methodology, from the perspective of materialistic, historical and dialectical analysis. We conclude that, given the socio-historical process of colonial-slave foundation, the structural difficulties of access to titling of quilombola territories act as mechanisms that perpetuate sequelae resulting from the slavery period, in the work and life relationships of Brazilian quilombolas, imposing restrictions on the experience of freedom, even after Abolition.

Keywords: Land concentration. Freedom. Quilombolas communities.

Recebido em 02.03.2021. Aprovado em 15.05.2021. Revisado em 12.07.2021.

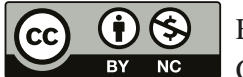

Este é um artigo publicado em acesso aberto (Open Access) sob a licença Creative Commons Attribution NonCommercial, que permite uso, distribuição e reprodução em qualquer meio, sem restrições desde que sem fins comerciais e que o trabalho original seja corretamente citado. 


\title{
Introdução
}

\author{
Confissões do latifúndio
}

Por onde passei, plantei a cerca farpada, plantei a queimada. Por onde passei, plantei a morte matada. Por onde passei, matei a tribo calada, a roça suada, a terra esperada... Por onde passei, tendo tudo em lei, eu plantei o nada.

(Pedro Casaldáliga).

O acesso das comunidades quilombolas aos territórios tradicionalmente ocupados no Brasil é fundamental para que nelas possam ser (re)organizadas possibilidades, de trabalho e vida, menos marcadas pelas continuidades das sequelas escravocratas no Brasil. O jogo de poder sobre quem pode ou não ter acesso à terra carrega impactos oriundos das bases do processo colonial-escravagista nacional, no qual a raça se constituiu em um importante marcador para negação da cidadania às pessoas negras, impulsionando dificuldades estruturais para o acesso de comunidades tradicionais à terra em favor da concentração fundiária.

Os quilombos, que simbolizam uma estratégia permanente de desgaste das relações escravistas no Brasil, sempre foram cruelmente combatidos e nomeados como espaços de crime. Após a Abolição, a resistência dos quilombos seguiu atuante nas comunidades quilombolas que herdam deles não apenas a resistência, mas o motivo central da existência da luta: a busca pelo reconhecimento do direito a um território coletivo onde possam trabalhar e viver, sem necessariamente estarem submetidos ao julgo de algum senhor do espaço onde vivem.

A partir desse processo histórico, sob a perspectiva de análise materialista, histórica e dialética, neste artigo trazemos um debate acerca do acesso à terra como elemento fundamental para as comunidades quilombolas, no que se refere ao avanço contra a permanência de elementos históricos forjados na estrutura fundiária herdeira das relações coloniais-escravagistas no Brasil. Para tanto, nos pautamos em uma abordagem qualitativa, na pesquisa bibliográfica e documental, esta a partir de documentos orais produzidos na Comunidade Quilombola do Grilo, estado da Paraíba, à luz da História Oral.

Como aproximações conclusivas, observamos que o processo histórico, que ordenou o traçado fundiário brasileiro, segue impactando as comunidades quilombolas e favorecendo fortes continuidades em relação à precarização do trabalho e da vida, uma vez que as dificuldades estruturais, para acessar a posse coletiva da terra, favorecem a permanência de traços herdados do trabalho escravo-colonial, mesmo após a Abolição da Escravidão e a generalização do trabalho livre, constituindo nas referidas comunidades experiências demarcadas pelo sentimento coletivo de seguir escravo em liberdade.

\section{Questão agrária e população negra no Brasil: entrelaces da liberdade negada}

A colonização compreendeu um sistemático processo de violência contra os povos colonizados e impactou povos africanos, que foram sequestrados para a escravização nas Américas e destituídos do reconhecimento de sua humanidade e liberdade, em um movimento no qual coletivamente se produziu "sociedades esvaziadas de si mesmas, culturas pisoteadas, instituições solapadas, terras confiscadas, [...] religiões assassinadas, [...] magnificências artísticas aniquiladas, [...] extraordinárias possibilidades suprimidas" (CÉSAIRE, 2020, p. 24-25).

Esse massacre dos territórios colonizados, aliado à escravização de povos africanos, foi uma importante base para o momento de acumulação primitiva do capitalismo, visto que

A descoberta das terras do ouro e da prata, na América, o extermínio, a escravização e o enfurnamento da população nativa nas minas, o começo da conquista e pilhagem das Índias Orientais, a transformação da África em um cercado para a caça comercial às peles negras marca a aurora da era de produção capitalista*. [...] O sistema colonial fez amadurecer como plantas de estufa o comércio e a navegação. [...] Às manufaturas em expansão, as colônias asseguravam mercado de escoamento e uma acumulação potenciada por meio do monopólio de mercado. O tesouro apresado fora da Europa diretamente por 
pilhagem, escravização e assassinato refluía à metrópole e transformava-se em capital (MARX, 1984, p. 370-372, grifo nosso).

A colonização do território na América colonial portuguesa permitiu à Coroa usufruir dos benefícios de se proclamar como legítima possuidora das terras que invadiu no Novo Continente, estabelecendo um modelo de organização social que foi dependente da mão de obra escravizada para se reproduzir e que constituiu bases fundamentais da sociedade brasileira, pois "o trabalho escravo modelou a sociedade brasileira [...] estabeleceu as relações de produção fundamentais na estrutura da sociedade e direcionou o tipo de desenvolvimento subsequente de instituições, de grupos e de classes" (MOURA, 2020, p. 16-17).

Abraçada à escravização, a vocação brasileira para concentração fundiária esteve presente desde as primeiras décadas da colonização. O surgimento das capitanias hereditárias e as sesmarias exemplificam o modelo fundiário que foi firmado, pelo projeto colonial português, na ocupação e exploração do território. Conforme Liberato (2008), o processo de privatização de terras coletivas dos povos indígenas brasileiros iniciou em 1530 com a implantação das sesmarias, e desde então a terra deixou de ser um bem comum e foi iniciado um desequilíbrio da estrutura fundiária brasileira. O sistema de sesmarias foi sucedido apenas pelo Regime de Posses que entrou em vigor a partir de 1822, já durante o processo de emancipação política do Brasil, e foi definitivamente regulamentado por meio da Lei $\mathrm{n}^{\circ} 601$ de 18 de setembro de 1850, a Lei de Terras (BRASIL, 1850a), um marco para o poderio do latifúndio brasileiro.

Os eleitos para serem senhores das terras foram também grandes senhores de escravizados. A Lei de Terras foi um dos aportes legais que entrelaçaram estes poderes, sobre a terra e sobre a gente. Já no Artigo $1^{\circ}$, a referida Lei anuncia: "Ficam proibidas as aquisições de terras devolutas por outro título que não seja o de compra" (BRASIL, 1850b). De pronto a Lei determinou que a terra fosse um bem, acima de tudo, comercial. É simbólico que a Lei de Terras seja do mesmo ano no qual se iniciaram as Leis Abolicionistas com a aprovação da Lei n 581 de 04 de setembro de 1850, conhecida como Eusébio de Queirós ${ }^{1}$ e que estabeleceu medidas para reprimir o tráfico de escravizados (BRASIL, 1850a). Nesse sentido, ao passo que o Império anunciou que africanos não seriam mais traficados para o Brasil, foi estabelecido que a população negra, ainda que liberta, não deveria ser dona de parte desse solo, pois, sendo a terra um bem comercial, no sistema escravocrata dificilmente os grupos que ocupavam a base da pirâmide social poderiam ter acesso ao poder de compra. Tal interdito ficou mais evidente no Artigo $2^{\circ}$ da Lei $n^{\circ} 601$ de 1850 :

Os que se apossarem de terras devolutas ou de alheias, e nellas derribarem mattos ou lhes puzerem fogo, serão obrigados a despejo, com perda de bemfeitorias, e de mais soffrerão a pena de dous a seis mezes do prisão e multa de $100 \$$, além da satisfação do damno causado. (BRASIL, 1850a).

A terra poderia ser de quem pudesse comprar ou herdar. Esse princípio manifestou a proteção que foi destinada às grandes propriedades agrárias e as relações de exploração que delas decorriam no Império. No que se refere à população negra, a mensagem evidente foi dada:

Os negros não tinham raízes aqui e nem deveriam criá-las. Seu contato com a terra seria mediado pela escravidão e não lhes seriam dadas condições de possuí-las quando estivessem livres do cativeiro. Uma vez libertos, tornavam-se estrangeiros, africanos e o que se esperava destes era o seu retorno aos seus lugares de origem. De acordo com o projeto de Estado brasileiro, a relação dos negros com a terra jamais deveria se constituir em bases estáveis. $\mathrm{O}$ acesso à terra permitiria a reprodução dos negros em outras circunstâncias, abriria espaço para a criação de raízes efetivas e à construção de um outro patamar a partir do qual se inseriria na sociedade brasileira (VILA NOVA; SANTOS, 2013, p. 21).

A recusa de incorporar positivamente a população negra na sociedade brasileira, sob a perspectiva da questão agrária nacional, impactou diretamente os quilombos ${ }^{2}$, que foram considerados essencialmente como um crime a ser combatido, enquanto vigorou a escravização. O quilombo significou, em regra para o Brasil colonial e imperial, uma ameaça aos povos civilizados, a expressão da barbárie e uma agressão à ordem social que trazia prejuízo ao trabalho e à produção de riqueza, por isso deveria ser perseguido até sua destruição (FIABANI, 2012). 
Caracterizar o quilombo consistia, portanto, em tipificar um crime com o objetivo de desarranjar as tentativas de organização de um modelo social que não estivesse alinhado ao poder dos grandes possuidores de terra e à fabricação de riqueza em favor da Coroa Portuguesa, durante a Colônia, e brasileira, no Império. Nesse sentido, as caracterizações legais que foram feitas para os quilombos, assim como as feitas sobre os escravizados que fugiam, tinham uma manifesta finalidade: tipificar um crime e identificar os que o cometiam para aplicar punição.

A perseguição aos quilombos foi incessante, pois, presentes em todo o território nacional, eles se constituíram como um fator efetivo de desgaste das relações escravistas, visto que eram numericamente expressivos e promoviam uma forte resistência ao sistema de forma permanente (MOURA, 2020).

Com o fim da escravização em 1888, viver em liberdade, fora do jugo das senzalas, deixou de ser crime. Todavia, aos quilombos seguiu a questão de estarem situados em terras que não eram suas legalmente, visto que em nome da concentração fundiária nacional, a partir de meados do século XIX, passou a ser ilegal toda forma de ocupação que não proviesse da compra (RIBEIRO, 2020). Desse modo, a situação dessas comunidades quanto ao acesso à terra não foi resolvida com a Lei Áurea, de forma que mesmo com a República, proclamada um ano após a Abolição da Escravidão, seguiu a imposição de maiores dificuldades para o acesso da população negra à terra.

\section{Negros no Brasil republicano: entre a cidadania negada e a liberdade sonhada}

Nas primeiras décadas republicanas, fins do século XIX e início do XX, novos arranjos sociais dificultaram o acesso da população negra à cidadania, impactando diretamente as comunidades quilombolas ${ }^{3}$ descendentes dos quilombos. Dois elementos centrais nesse momento, para o impacto social que foi imposto às(aos) negras(os), foram a forma como se deu a generalização do trabalho livre, alinhado à política de branqueamento, e o caráter conservador da modernização operada pelo capitalismo brasileiro, que refuncionalizou o latifúndio.

No Brasil, o aparecimento da questão social vinculou-se a generalização do trabalho livre em momento subsequente à Abolição, período em que a sociedade estava profundamente marcada por relações sociais escravistas (IAMAMOTO; CARVALHO, 2009). Essa transição do trabalho escravizado para o livre foi impactada pelo racismo estrutural, produzindo sequelas pujantes contra a população negra, no que diz respeito ao acesso à cidadania.

Foi só com a proximidade do fim da escravidão e da própria monarquia que a questão racial passou para a agenda do dia. Até então, enquanto "propriedade' o escravo era por definição o "não-cidadão". No Brasil, é com a entrada das teorias raciais, portanto, que as desigualdades sociais se transformaram em matéria da natureza. Tendo por fundamento uma ciência positiva e determinista, pretendia-se explicar com objetividade - valendo-se da mensuração de cérebros e da aferição das características físicas - uma suposta diferença entre os grupos. A "raça" era introduzida, assim, com base nos dados da biologia da época e privilegiava a definição dos grupos segundo seu fenótipo, o que eliminava a possibilidade de se pensar no indivíduo e no próprio exercício da cidadania e do arbítrio. Dessa maneira, em vista da promessa de uma igualdade jurídica, a resposta foi a "comprovação científica" da desigualdade biológica entre homens, ao lado da manutenção peremptória do liberalismo, tal como exaltado pela nova República de 1889. (SCHWARCZ, 2012, p. 38).

Dessa forma, com a Abolição da Escravidão e a Proclamação da República, muitos pensadores brasileiros ${ }^{4}$, sob influência do pensamento científico da Europa Ocidental, voltaram-se para pensar a construção da identidade nacional e dos rumos do país. A resposta a esses objetivos encontrou um problema central a ser resolvido: quais direcionamentos deveriam ser dados aos ex-escravizados? A tendência geral de resposta girou em torno de pensar meios para a máxima diluição desta nova categoria de cidadãos através do embranquecimento do país, pois os(as) negros(as) foram considerados(as) como um entrave ao progresso do país em face da proclamação científica de que eram inferiores (MUNANGA, 2008). Nesse sentido, a nova categoria de cidadãos foi de imediato rebaixada à de não cidadãos ou cidadãos de última classe.

Foi nesse momento que ocorreu a generalização do trabalho livre no Brasil vinculada à política de branqueamento populacional que usou o incentivo à imigração europeia como principal estratégia. Portanto, quando as portas das senzalas foram abertas, negros e negras foram recepcionados pela voz da ciência eugenista que, através de teorias raciais, anunciou: vocês são naturalmente inferiores e não cabem no ideal da nação 
republicana. Essa concepção assinalou um evidente contorno racial no mercado de trabalho. Após a Abolição, nos grandes centros urbanos que iniciaram o processo de industrialização, o acesso ao nascente mercado de trabalho foi negado à população negra. Sob a égide do capitalismo monopolista forma-se uma "massa marginal" quem tem cor: é negra. "A força de trabalho industrial em geral era composta maciçamente pelos imigrantes, chegando a compor quase 90\% dos braços operários" (SIMÃO, 1966 apud SEABRA, 2011, p. 03). É possível observar que, em nome de um ideal de branqueamento populacional, houve uma estratificação interna na força de trabalho, demarcando lugares nos quais os piores espaços foram reservados à população negra.

Se nas cidades a marca do desemprego é a tônica para a população negra, na área rural as relações de trabalho no pós-abolição foram marcadas pelo caráter conservador da modernização capitalista que revigorou o poder do latifúndio. A transição para o trabalho livre, nas áreas rurais, foi afetada por este quadro na medida em que não ocorreram transformações estruturais no setor agrário e uma série de vínculos característicos de formas produtivas anteriores foi mantida (GONZALEZ, 2020, p. 25). Essa permanência perpetuou elementos laborais escravistas de modo que, mesmo após a Lei Áurea, o trabalho livre trazia as marcas das senzalas. Com a Abolição foi estabelecido "um novo estado econômico, político, social e cultural de escravidão em liberdade" (NASCIMENTO, 2016, p. 81).

Com o raiar do século XX, o modelo agroexportador entrou em crise, mas isso não significou o fim do poderio das oligarquias rurais, o latifúndio foi revitalizado (STEDILI, 2005). A concentração fundiária seguiu sendo fortalecida impactando negativamente as comunidades rurais negras descendentes dos quilombos, que passaram a ser marcadas como um dos símbolos do atraso no desenvolvimento nacional, pois carregavam a marca da pequena e coletiva propriedade de terra e a marca da negritude, esta rechaçada como cientificamente inferior.

A ideia de que o progresso do país dependia não apenas do seu desenvolvimento econômico ou da implantação de instituições modernas, mas também do aprimoramento racial de seu povo, que dominou a cena política e influenciou decisões públicas das últimas décadas do século XIX, contribuindo efetivamente para o aprofundamento das desigualdades no país. (JACCOUD, 2008, p. 49).

As comunidades quilombolas se viram, então, diante de um quadro no qual o Estado manteve a questão agrária sob o controle do poder central "para viabilizar a sua política econômica. Por essa política, o acesso à terra ficou fechado aos camponeses e totalmente aberto à empresa capitalista" (MORISSAWA, 2001, p. 99-100). O que se verificou foi que houve uma aliança entre a burguesia industrial e a oligarquia rural que ocorreu especialmente por dois motivos: o primeiro é o fato de a burguesia industrial brasileira ter origem na oligarquia rural, e o segundo diz respeito à condição dependente do modelo industrial nacional que precisou da continuidade das exportações agrícolas para se firmar (STEDILI, 2005).

Nessa aliança entre a burguesia industrial e a oligarquia rural, firmada nas primeiras décadas republicanas, a população negra seguiu como o elemento mais indesejado e explorado da nação, nas cidades e no campo, diante de uma modernização conservadora que foi operada pelo capitalismo revigorando instituições que, em outros contextos, foram consideradas como entrave para a expansão capitalista. Em nosso país

O desenvolvimento capitalista operava-se sem desvencilhar-se de formas econômico-sociais que a experiência histórica tinha demonstrado que eram adversas; mais exatamente, o desenvolvimento capitalista redimensionava tais formas (por exemplo, o latifúndio), não as liquidava, refuncionalizava-as. Na formação social brasileira, um dos traços típicos do desenvolvimento capitalista consistiu precisamente em que se deu sem realizar as transformações estruturais que, noutras formações (as experiências euro-ocidentais), constituíram as suas pré-condições. No Brasil, o desenvolvimento capitalista não se operou contra o "atraso", mas mediante a sua contínua reposição em patamares mais complexos, funcionais e integrados (PAULO NETTO, 1996, p. 18).

Nesse contexto, a República Brasileira emergiu e consolidou-se sem realizar transformações estruturais fortalecendo um modelo produtivo no qual a industrialização, centrada no espaço urbano, e a grande propriedade rural, mantenedora de relações trabalhistas pré-capitalistas, eram faces de uma mesma moeda, de um mesmo movimento societário que estendeu os poderes do latifúndio revelando que no Brasil: 
[...] a propriedade da terra sempre esteve inserida no pleito da burguesia, no que diz respeito à defesa da propriedade privada e a consequente supremacia econômica. Compreendida como um dos meios de produção por viabilizar a realização da atividade produtiva, a terra preservou sua relevância nas fases do capitalismo (mercantil ou comercial, industrial ou financeiro) (RIBEIRO, 2020, p. 18).

Sob este quadro, as comunidades quilombolas atravessaram o século XX subjugadas a relações de trabalho nas quais a superexploração e a ausência de acesso a direitos trabalhistas foram uma constante. Entre o trabalho nas terras de algum herdeiro das casas grandes e a migração para os centros urbanos como tentativa (em regra, frustrada) de melhorar as condições de vida, os quilombolas se viram entre a cidadania negada e a liberdade que seguia sendo sonhada, como já o era para seus ancestrais, e que só poderia ser experimentada com o acesso aos seus territórios tradicionalmente ocupados, para que fosse possível romper com a condição de só ter direito ao pedaço de terra que com palmos é medida, como parte que lhe cabe neste latifúndio ${ }^{5}$ chamado Brasil.

Durante o primeiro século da República, não foram efetivadas ações em favor do acesso à terra para comunidades quilombolas no Brasil. Foi apenas com a Constituição Federal de 1988, cem anos após a Lei Áurea, que se "inseriu o direito de propriedade no rol dos direitos fundamentais, ressaltando [...] a importância do direito social ínsito na propriedade" (LIBETARO, 2008, p. 53) e que se assegurou às comunidades quilombolas, por meio do Artigo 68, o direito de titulação dos territórios tradicionalmente ocupados. Ainda que isto não tenha significado que os entraves para acessar este direito tenham cessado, foi um importante avanço mesmo que tardio.

É importante destacar que é nesse momento que "a categoria legal, por meio da qual se classificava quilombo como crime, passou a ser considerada como categoria de autodefinição, voltada a reparar danos e a acessar direitos" (ALMEIDA, 2002 apud BRASIL, 2009, p. 13). Assim, o quilombo foi considerado crime durante o período monárquico e mesmo após a Abolição nosso país esqueceu de reclassificá-lo por um século. Este fato seguiu como indicativo da continuidade do poder do latifúndio no Brasil.

\section{O acesso à terra e a experiência de liberdade: quilombos e quilombolas no Brasil}

A relação entre o acesso ao território e a liberdade sempre foi fundamental aos quilombos, ao passo que sempre causou também grande medo às autoridades monárquicas, não apenas porque cada escravizado que fugia representava individualmente uma perda econômica às casas grandes, mas pelo motivo de os quilombos, ao conquistarem seu "pedaço de chão", apresentarem à sociedade uma alternativa de organização social que não estava baseada na dependência da mão de obra escravizada. Um indício disto está no conceito da Coroa Portuguesa sobre quilombo que foi consagrado pela historiografia brasileira.

A definição mais citada pela historiografia foi a do rei de Portugal, Dom João V, em resposta à consulta do conselho Ultramarinho datada de 2 de dezembro de 1740: “[...] toda habitação de negros fugidos que passem de 5, em parte despovoado, ainda que não se tenham ranchos levantados nem se achem pilões neles" (FIABANI, 2012, p. 267, grifo nosso).

Essa concepção de quilombo também apareceu em formulações legais posteriores à de Dom João V, isso se deveu ao fato de que o pilão era "o símbolo de autoconsumo e capacidade de reprodução" (ALMEIDA, 2002 apud FIABANI, 2012, p. 67) e também um instrumento importante para a produção de refeições a partir de grãos. Portanto, o pilão indicava que, além de haver fixação territorial, havia estabilidade com produção agrícola, revelando que os quilombos organizaram formas de microssociedades alternativas ao trabalho escravizado na sociedade colonial (FIABANI, 2012, p. 67). A continuidade da organização de quilombos, mantida durante todo o período monárquico, se revelou um perigo à sociedade vigente, pois sua experiência histórica evidenciou que:

[...] o trabalho é antes uma forma de libertação humana que o cidadão desfruta como um direito e uma obrigação social. Liberto da exploração e do jugo embrutecedor da produção tecno-capitalista, a desgraça do trabalhador deixará de ser o sustentáculo de uma sociedade burguesa parasitária que se regozija no ócio de seus jogos e futilidades (NASCIMENTO, 1980, p. 264). 
Posse e uso coletivo da terra estiveram na base da concepção de liberdade que norteava os quilombos. Essa concepção não foi absolutamente rompida e traços dela sobreviveram nas comunidades quilombolas que carregam o histórico da busca por liberdade, tendo no acesso a seus territórios tradicionalmente ocupados uma demanda central, pois "a terra, evidentemente, é crucial, para a continuidade do grupo, do destino dado ao modo de vida destas populações [...] a terra é o que propicia condições de permanência [...] de referências simbólicas importantes" (LEITE, 2000, p. 344-345).

O Quilombo dos Palmares, "maior manifestação de rebeldia contra o escravismo na América Latina" (MOURA, 2020, p. 59), oferece exemplos interessantes sobre o modelo de economia antiescravista que foi desenvolvido, entrelaçando a perspectiva de liberdade ao território ocupado. À época de Palmares, a economia latifundiária-escravista açucareira produzia para o mercado internacional. Porém, os ganhos com a produção não ficavam na Colônia, onde o povo tinha um baixíssimo nível de vida. Em Palmares, todavia, foi organizado um sistema de produção diversificado que se chocava com esse modelo colonial e estava baseado no trabalho cooperativo e comunitário (MOURA, 2020).

Palmares foi a negação, pelo exemplo de seu dinamismo econômico, político e social, da estrutura escravagista-colonialista. $\mathrm{O}$ seu exemplo era um desafio permanente e um incentivo às lutas contra o sistema colonial em seu conjunto. Daí Palmares ter sido considerado um valhacouto de bandidos e não uma nação em formação. A sua destruição, o massacre da Serra da Barriga, [...] o aprisionamento e eliminação de seus habitantes e, finalmente, a tentativa de apagar-se da consciência histórica do povo esse feito heroico foram decorrência de sua grande importância social, política e cultural (MOURA, 2020, p. 92).

Não houve, obviamente, uma única forma de organização para todos os quilombos, eles apresentavam uma estruturação diversa. Todavia a sua formação e multiplicação, por si, representavam uma ameaça, pois traziam a materialização de formas de liberdade do cativeiro no interior da sociedade escravista, ainda que sob as condições mais adversas. A relação desta busca por materializar formas de liberdade com o território ocupado era intrínseca e não se rompeu completamente nas comunidades quilombolas, de modo que para estas o acesso à titulação de suas terras segue sendo uma demanda central.

Esse elo entre território e concepção de liberdade, com suas rupturas e continuidades históricas, pode ser observado ainda na atualidade nas comunidades quilombolas. A partir da teia da historicidade aqui apresentada, exemplificamos a questão a partir da Comunidade Quilombola do Grilo, no estado da Paraíba, na qual podemos perceber um exemplo da materialização do significado das terras, tradicionalmente ocupadas pela comunidade, como mecanismo de busca pela liberdade em relação a alguns laços do passado escravocrata, manifestos nas relações de trabalho às quais seus membros foram submetidos após a Abolição.

A Comunidade do Grilo está localizada na microrregião do agreste paraibano. A sua formação remonta ao passado escravocrata brasileiro. Dona Lourdes, uma das lideranças mais idosas da comunidade, nos informa ${ }^{6}$ sobre a gênese da comunidade: "Meu tataravô veio pra cá fugido [...] ele veio para cá com seus dezenove anos fugido de um canto [...]. Viajou muito tempo de pé, de mata adentro para poder encontrar"’ (M.L.T.C., 2017). A imagem da fuga desse antepassado, lembrado como "pai Manoel", se repete, nas palavras do senhor Elias (irmão de Dona Lurdes):

Ele foi trazido pra cá e pegado a dente de cachorro no mato, quer dizer, é a pessoa viver na escravidão ou queria fugir alguma coisa assim, né? Então ela conta, naquele tempo era escravizado mesmo, não tinha como, a pessoa morava numa fazenda da serra como escravo, de qualquer maneira tinha descendência de escravo, mesmo querendo ou não, querendo não, porque, era mesmo, era escravo de qualquer maneira (E.C.T., 2017)

A ideia de escravidão que emerge dessa fala aponta para dois elementos centrais. O primeiro deles é a fuga permeada por processos de extrema violência, visto que Pai Manoel foi perseguido, caçado, por cachorros. O segundo elemento é a memória transmitida sobre ele fugir de uma fazenda onde morava como escravizado; se ele era ainda legalmente escravizado ou descendente de escravizados, é indiferente para Elias, pois em ambas as hipóteses ele vivia sob a permanência das condições do trabalho escravo como era antes da Lei Áurea. Isso indica que a relação com a terra e a forma de trabalho desenvolvido sobre ela é crucial para 
a concepção de liberdade entre lideranças da comunidade quilombola do Grilo. Essa concepção é reforçada quando Dona Lourdes fala sobre o porquê de ela considerar que o território onde vivem sempre deveria ter sido reconhecido como propriedade da comunidade:

A gente dizia que deveria ser da gente, porque a gente 'nascemo' e se criou aqui, nossos pais trabalhava de graça pra eles, só tinha o direito de folgar no domingo, trabalhava no roçado, e tinha que ser da gente mesmo [a propriedade da terra]. Eles acabaram com a vida do meu pai, mas com a da gente não conseguiram acabar não. Porque meu pai morreu 'estazado' trabalhando. Só sei que quando ele se casou ele ainda trabalhava pra o patrão bem dizer de graça, e pai já tava bem fraco. O patrão levou pai pra fazer uma consulta em João Pessoa, aí quando chegou lá meu pai, sem saber de nada, o médico perguntou se ele trabalha muito e o patrão disse que não. Ele enganou, né? Mesmo o meu pai "estazado" de trabalhar, o patrão levou ele porque sabia que ele tava quase morto (M.L.T.C. apud PINHEIRO, 2018) ${ }^{10}$.

Dona Lourdes sentencia que a terra deve ser de quem produz nela e não de quem explora o trabalhador até sua morte. Para a família de líderes comunitários, o fato de não se ter acesso a terra era uma óbvia continuidade da escravidão, o que fica evidenciado na fala de seu irmão Elias:

[...] meu pai foi morar nessa fazenda [...] trabalhava alugado de quatro dias por semana lá, ficava um dia só pra ele trabalhar no roçado, sujeito no sábado, que era o dia dele de ele ficar com a gente no roçado, tinha obrigação de ir pra [...] feira mais próxima aqui, pra fazer a feira dele [do fazendeiro] e tinha que ir, não podia se negar, quer dizer não é escravidão? É escravidão (E. C. T., 2017) ${ }^{11}$.

A partir desses relatos é possível perceber a presença das relações escravocratas na memória coletiva da comunidade. É interessante notarmos que a concepção de um antepassado ter sido escravizado não se liga, necessariamente, ao tempo cronológico anterior à Abolição por meio da Lei Áurea. O que se destaca é que no cotidiano da comunidade quilombola do Grilo a concepção de escravidão é marcada por traços e continuidades de sua origem histórica, sentenciada pelo jugo escravocrata e latifundiário, de modo que sua concepção de liberdade não se dissocia da posse comunitária da terra e da possibilidade de se estabelecer novas formas de trabalho sobre ela. Escravidão e liberdade não são, nesse contexto, concepções vinculadas à cronologia histórica e nem ao aparato legal sobre esses termos, são, antes, construídas com base nas muitas determinações da história vivida. Não há, para a comunidade, uma data e uma lei que marque a passagem da escravidão à liberdade, o que há são condições socio-históricas que permitem vivenciar mais as continuidades ou as rupturas do processo inacabado da Abolição.

\section{Considerações finais}

Colonização, escravização e concentração fundiária marcam as bases da formação nacional brasileira impactando profundamente os arranjos históricos, políticos e econômicos do país, mesmo após a Abolição e Proclamação da República. Quilombos e quilombolas foram e são marcados pelas continuidades dessas bases históricas, especialmente no que se refere ao acesso aos territórios tradicionalmente ocupados. Uma das sequelas desse processo está no fato de que os povos quilombolas têm dificuldades particulares de vivenciar a liberdade, anunciada por leis, sem acesso ao direito de ter onde viver preservando a (re)produção de bens materiais e simbólicos. Para eles, não há liberdade sem a terra.

Sabemos que a liberdade plena não pode ser alcançada sob a sociabilidade capitalista, considerando que ela "significa aquela forma de liberdade - grau máximo de liberdade possível para o homem - que o indivíduo tem como integrante de uma comunidade real, cujo fundamento é necessariamente o trabalho associado" (TONET, 2013, p. 22). Todavia, se não se alcança a liberdade plena em face de um modelo societário assentado sob o trabalho alienado, considerando os fundamentos da nossa história fundiária, aos povos quilombolas a negação da liberdade chega a ser vivenciada, ainda na atualidade, como impossibilidade de alcançar todos os efeitos da Lei Áurea. 


\section{Referências}

ARAÚJO, O. R. de; SANTOS, S. M. dos. História oral: vozes, narrativas e textos. Cadernos de História da Educação, Uberlândia, n. 6, jan./dez. 2007.

BRASIL. Lei n. 601, de 18 de setembro de 1850. Dispõe sobre as terras devolutas do Império. Brasília, DF: Presidência da República, 1850b. Disponível em: http://www.planalto.gov.br/ccivil_03/leis/10601-1850.htm. Acesso em: 17 maio 2021.

BRASIL. Lei $n^{\circ} 581$, de 4 de setembro de 1850. Estabelece medidas para a repressão do tráfico de africanos neste Império. Brasília, DF: Presidência da República, 1850a. Disponível em: http://www.planalto.gov.br/ccivil_03/leis/lim/lim581.htm\#: :text=LEI\%20 N\%C2\%BA\%20581\%2C\%20DE\%204\%20DE\%20SETEMBRO\%20DE\%201850.\&text=Estabelece\%20medidas\%20para\%20a\%20 repress $\% \mathrm{C} 3 \% \mathrm{~A} 3 \mathrm{o} \% 20 \mathrm{do} \% 20$ trafico\%20de\%20africanos\%20neste\%20Imperio. Acesso em: 17 maio de 2021.

BRASIL. Secretaria Especial de Políticas de Promoção da Igualdade Racial. Subsecretaria de Políticas para Comunidades Tradicionais. Programa Brasil Quilombola: comunidades quilombolas brasileiras: regularização fundiária e políticas públicas. Brasília, DF, 2009. CÉSAIRE, A. Discurso sobre o colonialismo. São Paulo: Veneta, 2020.

E.C.T. Elias Coelho TENÓRIO. $1^{\circ}$ depoimento [abr... 2017]. In: Entrevistadora: Alcione Ferreira da Silva. Trecho transcrito.

FIABANI, A. Mato, palhoça e pilão: o quilombo, da escravidão às comunidades remanescentes. São Paulo: Expressão Popular, 2005. GOMES, F. dos S. Mocambos e quilombos: uma história do campesinato negro no Brasil. São Paulo: Caro Enigma, 2015.

GONZALEZ, L. Cultura etnicidade e trabalho: efeitos linguísticos e políticos da exploração da mulher negra. In: RIOS, F.; LIMA, M. (org.). Por um feminismo afro-latino-americano. Rio de Janeiro: Zahar, 2020. p. 25-44.

IAMAMOTO, M. V. e CARVALHO, R. de. Relações Sociais e Serviço Social no Brasil: esboço de uma interpretação históricometodológica. São Paulo: Cortez, 2009.

JACCOUD, L. Racismo e República: o debate sobre o branqueamento e a discriminação racial no Brasil. In: THEODORO, M. (org.). As políticas públicas e a desigualdade racial no Brasil: 120 anos após a Abolição. Brasília: IPEA, 2008. p. 45-64.

L.C. T. S. Leonilda Coelho Tenório dos SANTOS. $1^{\circ}$ depoimento [abr. 2017]. In: Entrevistadora: Alcione Ferreira da Silva. Trecho transcrito.

LEITE, I. B. Os quilombos no Brasil: questões conceituais e normativas. Revista Etnográfica, Portugal, v. IV, n. 2, 2000. p. 333-345. LIBERATO, A. P. G. Reforma agrária: direito humano fundamental. Curitiba: Juruá, 2008.

MARX, K. O Capital: crítica da economia política. V. I. São Paulo: Abril Cultural, 1984.

M.L.T.C. Maria de Lourdes Tenório CÂNDIDO. $1^{\circ}$ depoimento [abr. 2017]. In: Entrevistadora: Alcione Ferreira da Silva. Trecho transcrito.

M.L.T.C. MARIA DE LOURDES TENÓRIO CÂNDIDO. In: PINHEIRO, C. L. M. et al. "Eles acabaram com a vida do meu pai": memórias da escravidão na comunidade Quilombola do Grilo -Paraíba. In: CONGRESSO NACIONAL DE EDUCAÇÃO, 5., 2018, Olinda: Realize, 2018. p. 1-12.

MORISSAWA, M. A História da Luta pela Terra e o MST. São Paulo: Expressão Popular, 2001. p. 99-100.

MOURA, C. Quilombos: resistência ao escravismo. São Paulo: Expressão Popular, 2020.

MUNANGA, K. Rediscutindo a mestiçagem no Brasil: identidade nacional versus identidade negra. Belo Horizonte: Autêntica, 2008. NASCIMENTO, A. do. O genocídio do negro brasileiro: processo de um racismo mascarado. São Paulo: Perspectivas, 2016. NASCIMENTO, A. do. Quilombismo. Petrópolis: Editora Vozes, 1980.

PAULO NETTO, J. Ditadura e serviço social: uma análise do serviço social no Brasil pós-64. São Paulo: Cortez, 2007.

RIBEIRO, A. L. R. C. Racismo estrutural e aquisição de propriedade: uma ilustração da cidade de São Paulo. São Paulo: Editora Contracorrente, 2020.

SCHWARCZ, L. M. Nem Preto nem branco, muito pelo contrário: cor e raça na sociedade brasileira. São Paulo: Claro Enigma, 2012. SEABRA, E. P. O movimento operário na primeira república. In: SIMPÓSIO NACIONAL DE HISTÓRIA. 26., 2011, São Paulo. Anais. São Paulo: ANPUH, 2011. p. 1-13.

STEDILI, P. (org.). A questão agrária no Brasil: o debate na esquerda 1960-1980. 1. ed. São Paulo: Expressão Popular, 2005.

TONET, I. Educar para a Cidadania ou para a Liberdade? Revista Perspectivas, Maceió, v. 23, n. 2, 2005.

VILA NOVA, A.; SANTOS, E. A. DOS. Mulheres Negras: histórias de resistência, de coragem, de superação e sua difícil trajetória de vida na sociedade brasileira. Duque de Caxias: Espaço Científico Livre Projetos Editoriais, 2013. 


\section{Notas}

1 A primeira lei a proibir o tráfico de escravizados foi a Lei de 7 de novembro de 1831. Todavia, apenas com a Lei Eusébio de Queirós o tráfico cessou de forma definitiva (RIBEIRO, 2020).

2 O termo "quilombo" só aparece nos documentos oficiais do período colonial no final do século XVII, anteriormente o termo utilizado era "mocambo" (GOMES, 2015).

3 Apenas a partir da Constituição de 1988 estas comunidades passaram a ser nomeadas como "quilombolas".

4 A destacar Silvio Romero, João Batista Lacerda, Nina Rodrigues, Oliveira Viana, conforme aponta Munanga (2008).

5 Trecho da música Funeral de Um Lavrador de autoria de Chico Buarque.

6 As fontes orais são analisadas a partir da História Oral, considerando que cada sujeito expressa uma perspectiva particular e humano-genérica concomitantemente, pois esta metodologia possibilita que acessemos aspectos individuais de quem nos fala, ao mesmo tempo em que entramos em contato com uma memória coletiva e o contexto socio-histórico no qual as falas são produzidas (ARAÚJO; SANTOS, 2007).

7 Entrevista concedida por Maria de Lourdes Tenório Cândido [2017]. Entrevistadora: Alcione Ferreira da Silva. Trecho transcrito. Trecho transcrito.

8 Entrevista concedida por Leonilda Coelho Tenório dos Santos [2017]. Entrevistadora: Alcione Ferreira da Silva. Trecho transcrito.

9 O termo se refere a um estado de adoecimento marcado por um profundo e permanente cansaço.

10 Entrevista concedida por Maria de Lourdes Tenório Cândido [2018]. Entrevistador: Caio Lucas Morais, 2017. Trecho transcrito.

11 Entrevista concedida por Elias Coelho Tenório [2017]. Entrevistadora: Alcione Ferreira da Silva. Trecho transcrito. Trecho transcrito.

\section{Alcione Ferreira da Silva}

alcionefs@hotmail.com

Mestra em Serviço Social pela Universidade Estadual da Paraíba

Professora substituta vinculada ao Departamento de Serviço Social da Universidade Estadual da Paraíba

(UEPB)

\section{UEPB}

Rua Baraúnas, 351, Bairro Universitário.

Campina Grande-PB

CEP 58429-500

\section{Agradecimentos}

Não se aplica.

Agência financiadora

Não se aplica.

Contribuições das autoras

$\mathrm{O}$ artigo foi elabora na íntegra pela autora.
Aprovação por Comitê de Ética

Não se aplica.

Consentimento para publicação

Não se aplica.

Conflito de interesses

Não há conflito de interesses. 